\title{
Knowledge of Selected Theoretical Colleges Students About Hepatitis C Virus Infection at Assiut University: Suggested Instruction Brochure
}

\author{
Sabreen Thabet Ali ${ }^{1}$, Shalabia Elsayed AboZead $^{2}$ \& Sahra Zaki Azer ${ }^{3}$ \\ B.Sc.Ng, Faculty of Nursing, Assiut University, Egypt. \\ Professor of Medical Surgical Nursing, Faculty of Nursing, Assiut University, Egypt. \\ Assistant Professor of Medical Surgical Nursing, Faculty of Nursing, Assiut University, Egypt.
}

\begin{abstract}
Aim: was to assess knowledge about hepatitis $\mathrm{C}$ virus infection at selected theoretical colleges' students at Assiut University and suggest instruction brochure. Research design: A cross-sectional survey based on a selfadministered questionnaire. Setting: The study was conducted at selected theoretical faculties (Faculty of Law, Commerce, and Art). Samples: The study sample consisted of (1000) adult students attending faculties of Law, Commerce, and Art. Age from 18 to 24 years, study years from $1^{\text {st }}$ until $4^{\text {th }}$ study years, males and females. Tools: Self-structured questionnaire sheet: It consisted of two parts: Socio demographic data \& Part (2): Assessment of students' knowledge about HCV developed and provided brochure for students about HCV. Results: The highest percentage of the sample (number of students) equally from law and commerce were (40\%) from each faculty. Concerning gender; females $(73.5 \%)$ from $1^{\text {st }}$ until $4^{\text {th }}$ class $(25 \%)$ in each class. More than half of sample $(52.2 \%)$ had poor knowledge level about hepatitis $\mathrm{C}$ virus. Conclusion: The majorities of samples who had good knowledge level were females, fourth class, and from urban area. Recommendation: Sufficient relevant suggested instruction brochure \& health instruction programs to facilitate educating students in theoretical colleges about mode of transmission and prevention of hepatitis $\mathrm{C}$.
\end{abstract}

\section{Keywords: Hepatitis C, Infection Control, Knowledge, Students, Instruction Brochure.}

\section{Introduction}

Hepatitis is inflammation of the liver. There are several hepatitis viruses they have been named as A, $\mathrm{B}, \mathrm{C}, \mathrm{D}, \mathrm{E}, \mathrm{F}$ (not confirmed) and $\mathrm{G}$, most common hepatitis viruses are as $\mathrm{A}, \mathrm{B}$, and $\mathrm{C}$ respectively (WHO, 2012).

Viral hepatitis is a global public health problem affecting millions of people every year, causing disability and death. Millions of people are living with viral hepatitis and millions more are at risk. Most people who were infected long ago with HBV or HCV are unaware of their chronic infection. They are at high risk of developing severe chronic liver disease and can unknowingly transmit the infection to other people (WHO, 2012, Abd El-Nasser \& Abed El baset, 2013).

According to World Health Organization (WHO), there are 350 million people with chronic HBV infection and 170 million people with chronic HCV infection worldwide (Tazeem et al., 2014)

Hepatitis $\mathrm{HCV}$ is contagious and easy to be transmitted from one infected individual to another by unsafe use of therapeutic injections, blood transfusion, shaving from barbers, tattooing (Naseer, et al., 2010), mother to child, unprotected sexual intercourse, sharing of eating utensils and beauty salon equipment (Yayehyirad, et al., 2009)

Egypt has the largest epidemic of HCV in the world, the sample included both urban and rural populations and included all 27 governorate of Egypt, over
11,000 individual (percentage of people) $14.7 \%$ were positive for HCV antibody (El-Zanaty et al., 2009). Incidence rates are estimated at 2-6 per 1000 per year, that is, at least 170,000 new cases every year, which means maintaining a prevalence rate of $5-15 \%$ in the foreseeable future, the age groups suffer prevalence rates of up to $50 \%$. As for the geographical distribution of anti-HCV in persons aged 10-50 years: the Nile Delta and Upper Egypt have rates of $28 \%$ and $26 \%$ respectively (El-Sayed, 2014).

Health education about hepatitis $\mathrm{B} / \mathrm{C}$ infections by running awareness programs was found necessary for all students especially for non-biological sciences students in order to improve awareness of this disease (Razi, et al., 2010, Abd El-Nasser \& Abed El baset, 2013).

Awareness, the state of condition of being aware, having knowledge, consciousness, and the object of the information drive is to raise awareness of what spreads. Interpreted information; understanding that germinates combination of data, and information (Essa et al., 2007).

\section{Significance of the study}

The researchers observed that theoretical colleges students had lack of knowledge and about virus $\mathrm{C}$ as regard (definition, causes, mode of transmissions, prevention and precautions). So our research was designed for assessment of theoretical students' 
knowledge and awareness' about virus $\mathrm{C}$ and provides them by suggested guidelines for raising their knowledge regarding this disease.

\section{Aim of the study}

To assess knowledge of selected theoretical colleges' students about hepatitis $\mathrm{C}$ virus infection and suggest instruction brochure .

\section{Research question}

What is the level of knowledge to work HCV among theoretical college's students?

\section{Subjects and method \\ Research design}

A cross-sectional survey research design was carried based on a self-administered questionnaire. It was conducted among the undergraduate students (from fourth study years).

\section{Setting}

The study was conducted at selected theoretical faculties at Assiut University (Faculty of Law, Commerce, and Art).

\section{Study subjects}

The study sample included $10 \%$ from undergraduate students from previously mentioned selected theoretical faculties' who agreed to participate in this study from their fourth years. The study sample (1000) adult students attending faculties of Law, Commerce, and Art at Assiut University, the study sample was selected according to the following criteria: age from 18 to 24 years, study years from $1^{\text {st }}$ until $4^{\text {th }}$ study years. Males and females. The study was done in a period of 6 months.

\section{Tools of data collection}

Self-structured questionnaire sheet: It consisted of two parts

\section{Part (1): Demographic data}

Such as (age, gender, and study year)

Part (2): Knowledge about HCV: to assess knowledge about HCV including (definition, causes, modes of transmission, prevention and precautions).

\section{Scoring system}

The scale consisted of 7 questions, 5 close ended questions of them took one score if the answer is correct and zero if the answer incorrect, one open ended question had score of 4 degrees, and one question contains of 9 choices but the correct choices are 5 choices, then the total scale have score of 14 degrees.

The total score transformed into percentage

$<50 \%=$ poor

$50-70=$ fair

$>70=$ good

\section{Methods}

An official approval letter was taken from the dean of faculty of nursing at Assiut University to dean of faculties of Law, Commerce, and Art.

- The purpose of the study was explained to the students prior to answering the questions, the study carried out before lecture of the students.

- A pilot study was carried out on 10\% (100) of the students to test the applicability and the feasibility of the tool then the necessary modifications were done according to the results of the pilot study.

- The researcher instructed the students on how to fill out the questionnaire completely and truthfully.

- The questionnaire was full out through interviewing students of each faculty (50 students per each class) during the first three days of each week, each student took 20-30 minutes to fill out sheet, the researcher clarified any questions that students needed.

- The content validity: the designed tools were judged by a jury of 5 experts from nursing staff from faculty of nursing at Assiut University, and their opinion were elicited regarding the tool format layout, relevance, comprehensiveness and consistency.

- Data privacy of the students were ascertained.

- The purpose and nature of the study was explained.

- The data collected during the period from January 2016 until May 2016.

- Self administrated questionnaire tool was all filled through interviewing group of 50 students

- The final form of the tools were designed and tested for reliability by using internal consistency for the tools measured using Cronbach test, the tools proved to be reliable at $(0.73)$.

Ethical considerations

- Research proposal was approved from ethical committee in the faculty of nursing

- There was no risk for study subjects during application of the research

- Formal consent was obtained from students who are willing to participate in the study, after explaining the nature and purpose of the study

- Confidentiality of data was assured

- Study subject have the right to refuse to participate and or withdraw from the study without any rational any time

- Study subject privacy was considered during collection data

\section{Brochure}

It was developed by the researcher based on literature review, it consisted of information about anatomy of the liver and its function, information about incidence of hepatitis $\mathrm{C}$, methods of transmissions of infection, diagnosis, complications (cirrhosis and cancer), how 
to prevent hepatitis $\mathrm{C}$, and nursing precaution regarding hepatitis $\mathrm{C}$ and treatment.

\section{Statistical analysis}

The data were tested for normality using the Anderson-Darling test and for homogeneity variances prior to further statistical analysis. Categorical variables were described by number and percent $(\mathrm{N}, \%)$,. Chi-square test and fisher exact test used to compare between categorical variables A twotailed $\mathbf{p}<\mathbf{0 . 0 5}$ was considered statistically significant. All analyses were performed with the IBM SPSS 20.0 software.

\section{Results}

Table (1): Distribution of the studied sample as regards their demographic characteristics (n=1000).

\begin{tabular}{|c|c|c|}
\hline Variable & No. & $\%$ \\
\hline $\begin{array}{l}\text { 1. Faculty } \\
-\quad \text { Faculty of Art } \\
-\quad \text { Faculty of law } \\
-\quad \text { Faculty of commerce }\end{array}$ & $\begin{array}{l}200 \\
400 \\
400\end{array}$ & $\begin{array}{l}20.0 \\
40.0 \\
40.0\end{array}$ \\
\hline $\begin{array}{l}\text { 2. } \\
\text { - } \text { Gender } \\
-\quad \text { Male } \\
-\quad \text { Female } \\
\end{array}$ & $\begin{array}{l}265 \\
735 \\
\end{array}$ & $\begin{array}{l}26.5 \\
73.5 \\
\end{array}$ \\
\hline $\begin{array}{l}\text { 3. Year of education: year } \\
-\quad \text { First class } \\
-\quad \text { Second class } \\
-\quad \text { Third class } \\
-\quad \text { Fourth class }\end{array}$ & $\begin{array}{l}250 \\
250 \\
250 \\
250\end{array}$ & $\begin{array}{l}25.0 \\
25.0 \\
25.0 \\
25.0\end{array}$ \\
\hline $\begin{array}{cc}\text { 4. } & \text { Residence } \\
- & \text { Urban } \\
- & \text { Rural }\end{array}$ & $\begin{array}{l}448 \\
552\end{array}$ & $\begin{array}{l}44.8 \\
55.2\end{array}$ \\
\hline
\end{tabular}

Table (2): Distribution of the studied sample as regards their knowledge about hepatitis virus (n=1000).

\begin{tabular}{|c|c|c|}
\hline Variable & No. & $\%$ \\
\hline $\begin{array}{l}\text { 1. Have you heard of viral hepatitis before? } \\
- \text { Yes } \\
- \text { No }\end{array}$ & $\begin{array}{l}894 \\
106 \\
\end{array}$ & $\begin{array}{l}89.4 \\
10.6 \\
\end{array}$ \\
\hline $\begin{array}{l}\text { If yes, Define viral hepatitis? } \\
-\quad \text { Don't hear about hepatitis viruses } \\
-\quad \text { Correct } \\
-\quad \text { Incorrect }\end{array}$ & $\begin{array}{l}106 \\
500 \\
394\end{array}$ & $\begin{array}{l}10.6 \\
50.0 \\
39.4\end{array}$ \\
\hline $\begin{array}{l}\text { 2. Are there types of hepatic infections? } \\
-\quad \text { Don't hear about hepatitis viruses } \\
-\quad \text { Yes } \\
-\quad \text { No }\end{array}$ & $\begin{array}{l}106 \\
645 \\
249\end{array}$ & $\begin{array}{l}10.6 \\
64.5 \\
24.9\end{array}$ \\
\hline $\begin{array}{l}\text { If yes, what's a type? } \\
-\quad \text { A } \\
-\quad \text { B } \\
-\quad \text { C } \\
-\quad \text { D }\end{array}$ & $\begin{array}{c}137 \\
206 \\
424 \\
50\end{array}$ & $\begin{array}{c}13.7 \\
20.6 \\
42.4 \\
5.0\end{array}$ \\
\hline $\begin{array}{l}\text { 3. Do you know the symptoms of hepatitis C? } \\
- \text { Don't hear about hepatitis viruses } \\
-\quad \text { Yes } \\
- \text { No }\end{array}$ & $\begin{array}{l}106 \\
384 \\
510\end{array}$ & $\begin{array}{l}10.6 \\
38.4 \\
51.0\end{array}$ \\
\hline $\begin{array}{l}\text { If yes, what's symptoms? } \\
-\quad \text { Correct } \\
-\quad \text { Incorrect }\end{array}$ & $\begin{array}{l}122 \\
262\end{array}$ & $\begin{array}{l}12.2 \\
26.2\end{array}$ \\
\hline
\end{tabular}




\begin{tabular}{|c|c|c|}
\hline Variable & No. & $\%$ \\
\hline $\begin{array}{l}\text { 4. Do you know the ways of diagnosing hepatitis C virus? } \\
-\quad \text { Don't hear about hepatitis viruses } \\
-\quad \text { Yes } \\
-\quad \text { No }\end{array}$ & $\begin{array}{l}106 \\
105 \\
789\end{array}$ & $\begin{array}{l}10.6 \\
10.5 \\
78.9\end{array}$ \\
\hline $\begin{array}{l}\text { If yes, what's it? } \\
-\quad \text { Correct } \\
-\quad \text { Incorrect }\end{array}$ & $\begin{array}{l}33 \\
72\end{array}$ & $\begin{array}{l}3.3 \\
7.2\end{array}$ \\
\hline $\begin{array}{l}\text { 5. Do you know ways for treatmentt viral hepatitis C? } \\
-\quad \text { Don't hear about hepatitis viruses } \\
-\quad \text { Yes } \\
- \text { No }\end{array}$ & $\begin{array}{c}106 \\
78 \\
816\end{array}$ & $\begin{array}{c}10.6 \\
7.8 \\
81.6\end{array}$ \\
\hline $\begin{array}{l}\text { If yes, what's it? } \\
-\quad \text { Correct } \\
-\quad \text { Incorrect }\end{array}$ & $\begin{array}{l}37 \\
41\end{array}$ & $\begin{array}{l}3.7 \\
4.1\end{array}$ \\
\hline $\begin{array}{ll}\text { 6. } & \text { Do you know ways to prevent viral hepatitis C? } \\
- & \text { Don't hear about hepatitis viruses } \\
- & \text { Yes } \\
- & \text { No }\end{array}$ & $\begin{array}{l}106 \\
170 \\
724\end{array}$ & $\begin{array}{l}10.6 \\
17.0 \\
72.4\end{array}$ \\
\hline $\begin{array}{l}\text { If yes, what's it? } \\
-\quad \text { Correct } \\
-\quad \text { Incorrect }\end{array}$ & $\begin{array}{l}120 \\
50\end{array}$ & $\begin{array}{l}12.0 \\
5.0\end{array}$ \\
\hline 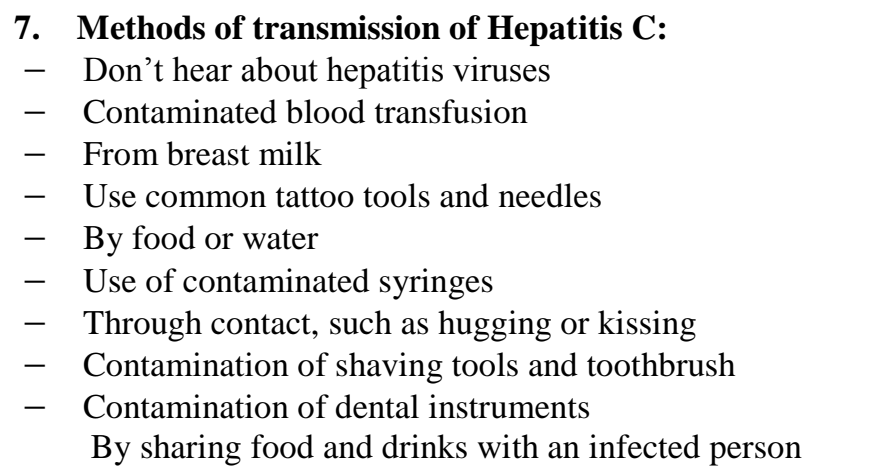 & $\begin{array}{c}106 \\
723 \\
170 \\
87 \\
379 \\
623 \\
257 \\
433 \\
367 \\
596\end{array}$ & $\begin{array}{c}10.6 \\
72.3 \\
17.0 \\
8.7 \\
37.9 \\
62.3 \\
25.7 \\
43.3 \\
36.7 \\
59.6\end{array}$ \\
\hline
\end{tabular}

Table (3): Distribution of the studied sample as regards their knowledge level about hepatitis C virus (1000).

\begin{tabular}{|l|c|c|}
\hline \multicolumn{1}{|c|}{ Variable } & No. & \% \\
\hline Knowledge level & 520 & 52.0 \\
\hline- Poor & 276 & 27.6 \\
\hline- Fair & 204 & 20.4 \\
\hline- Good & \multicolumn{2}{|c|}{} \\
\hline
\end{tabular}


Table (4): Relation between knowledge level and demographic data.

\begin{tabular}{|c|c|c|c|c|c|c|c|}
\hline \multirow{3}{*}{ Variable } & \multicolumn{6}{|c|}{ Knowledge level } & \multirow{3}{*}{ P. value } \\
\hline & \multicolumn{2}{|c|}{ Poor } & \multicolumn{2}{|c|}{ Fair } & \multicolumn{2}{|c|}{ Good } & \\
\hline & N. & $\%$ & N. & $\%$ & N. & $\%$ & \\
\hline \multicolumn{8}{|l|}{ 1. Faculty } \\
\hline - Faculty of Art & 106 & 20.4 & 60 & 21.7 & 34 & 16.7 & \multirow{3}{*}{0.160} \\
\hline - Faculty of law & 192 & 36.9 & 118 & 42.8 & 90 & 44.1 & \\
\hline - Faculty of commerce & 222 & 42.7 & 98 & 35.5 & 80 & 39.2 & \\
\hline \multicolumn{8}{|l|}{ 1. Gender: } \\
\hline - Male & 219 & 42.1 & 34 & 12.3 & 12 & 5.9 & \multirow{2}{*}{$\begin{array}{c}<0.001 * \\
*\end{array}$} \\
\hline - Female & 301 & 57.9 & 242 & 87.7 & 192 & 94.1 & \\
\hline \multicolumn{8}{|c|}{ 2. Year of education year: } \\
\hline - First class & 199 & 38.3 & 28 & 10.1 & 23 & 11.3 & \multirow{4}{*}{$\begin{array}{c}<0.001 * \\
*\end{array}$} \\
\hline - Second class & 156 & 30.0 & 52 & 18.8 & 42 & 20.6 & \\
\hline - Third class & 109 & 21.0 & 85 & 30.8 & 56 & 27.5 & \\
\hline - Fourth class & 56 & 10.8 & 111 & 40.2 & 83 & 40.7 & \\
\hline \multicolumn{8}{|l|}{ 3. Residence: } \\
\hline - Urban & 178 & 34.2 & 123 & 44.6 & 147 & 72.1 & \multirow{2}{*}{$\begin{array}{c}<0.001 * \\
*\end{array}$} \\
\hline - Rural & 342 & 65.8 & 153 & 55.4 & 57 & 27.9 & \\
\hline
\end{tabular}

** Statistically significant difference $(p<0.01)$

Table (1): this table shows that the highest percentage of the study students equally were from faculty of law and commerce (40\%) from each faculty. Concerning gender the majority were females $(73.5 \%)$, from $1^{\text {st }}$ to $4^{\text {th }}$ class $(25 \%)$ in each class. More than half of the sample were from rural area $(55.2 \%)$.

Table (2): In this table, the majority of sample (89.4\%) have knowledge about hepatitis $\mathrm{C}$ before and less than half of the sample (42.4\%) know hepatitis C.

Half of the sample $(50 \%)$ have knowledge about correct definition of hepatitis C. More than two thirds of them (64.5\%) had correct answer about hepatitis C. Regarding methods of transmission of hepatitis $\mathrm{C}$ more than two third (72.3\%) had correct answer as regards the contaminated blood transfusion is most common methods of its transmission.

Regarding knowledge related to symptoms of hepatitis $\mathrm{C}$ more than one third (38.4\%) had correct answer. Ways of prevention of viral hepatitis $\mathrm{C}$ the students who had correct answer were $(17.0 \%)$. The students who had correct answer regarding knowledge related ways of prevention of hepatitis $\mathrm{C}$ virus were $(12.0 \%)$

Table (3): This table mentioned that a bout than half of the sample $(52.2 \%)$ had poor knowledge level about hepatitis $\mathrm{C}$ virus

Table (4): This table illustrates that, there was a statistically significance relation between knowledge level and demographic data in the study samples in all items except types of faculties. Whereas the majority of samples (94.1\%) who had good knowledge level and were females, at fourth class (40), and from urban area (72.1\%).

\section{Discussion}

Hepatitis is a public health threat particularly in Egypt requiring prompt attention. Counseling and health education about epidemiology and medical aspects of the disease would probably improve knowledge and attitude. To control infection, efforts should be spent to raise awareness about hepatitis and their prevention or modifying people's behavior. Reduction of the burden of disease in Egypt may be through the educational campaigns (Hassan et al., 2012).

The aim of this study was to assess knowledge of selected theoretical colleges' students about hepatitis $C$ virus infection and suggest instruction brochure at Assiut University.

Based on the results of the present study, the highest percentage of the study students were equally from law and commerce and represented more than one third, and more than two thirds were females This result was in the same line with (Abd El-Nasser \& Abed El baset 2013) who mentioned that more than one third of the students were from faculty of arts, one third from faculty of nursing, less than quarter from faculty of commerce and education, and also, reported that more than two thirds of total students were females.

The current study showed that the number and percentage of students as regards the year of education equally and were from $1^{\text {st }}$ to $4^{\text {th }}$ class. 
According to Tazeem et al., (2014) who revealed that Fourth year students made the majority with $28.6 \%$ along with first year $(25.7 \%)$, third year $(24.3 \%)$ and second year students $(21.4 \%)$.

Regarding residence, more than half of the sample were from rural area. This result was in the same line with Housman \& Odum, (2015); who mentioned that; more than half of students were from rural area. Regarding knowledge related to definition of viral hepatitis; the majority of the sample was having knowledge about hepatitis $\mathrm{C}$ before. Concerning methods of transmission of hepatitis $\mathrm{C}$; more than two thirds had correct answer the contaminated blood transfusion most common methods of transmission. This result was in the same line with (Tazeem et al., 2014) who stated that, the majority of the students knew about hepatitis B and C. Also, stated the majority of the study sample identified blood and blood products and almost same number of participants voted for needles and sharps along with mentioned sexual intercourse as correct routes of transmission. Also stated that,

The current study presented that half of the sample had knowledge about correct definition of hepatitis $\mathrm{C}$. More than two third of them have correct answer about hepatitis C. Also, Abd El-Nasser \& Abed El baset (2013) agreed with the researcher's opinion and reported that; more than half of students had got knowledge regarding identification of virus and type of viruses. Also, revealed that the major source of information regarding hepatitis $\mathrm{B} / \mathrm{C}$ was from classroom lectures and doctors, followed by family, friends, neighbors and teachers.

Also, Maroof et al., (2012) reported that, more than one third of the sample knew that unsafe blood transfusion is a risk factor for hepatitis $\mathrm{C}$, where prevalence of knowledge regarding reused needles and unsafe sex are risk factors was reported by one fifth and one tenth of the respondents respectively.

The results of the current study showed that, the majority of students had inadequate knowledge related to ways of prevention of hepatitis $\mathrm{C}$ virus. Anjali \& Shikha, (2011) was also in the same line and reported that; the knowledge of students about hepatitis $\mathrm{B}$ and $\mathrm{C}$ and the use of preventive measures was inadequate.

The data of the study results illustrate that more than half of the sample had poor knowledge level about hepatitis C virus. In a report by Razi et al., (2010) who mentioned that, in Pakistan, the survey showed fair level of knowledge among university students regarding hepatitis $\mathrm{B}$ and $\mathrm{C}$, but gaps in knowledge were identified which need to be strengthened in students especially in non-biological sciences group. Also, Razi et al., (2010) added that knowledge, attitude and practice studies are useful steps to asses extent to which an individual or community is in a position to adopt a disease risk-free behavior for this disease.

According to Ibrahim \& Madian (2011): who mentioned that, Ministry of Health activities, hospitals and specialized centers activities and educational campaigns activities are important to increase awareness of population at risk and general population. These activities should have the priority to encourage people to take a more active role in preventing exposure to $\mathrm{HCV}$ and/or modifying their behavior that permit transmission of $\mathrm{HCV}$ to reduce the burden of $\mathrm{HCV}$ disease on health related quality of life (Qol) of infected patients in Egypt

This results of the current study showed that, there were statistical significant relation between knowledge level and demographic data in the study samples in all items except types of faculties. The current study finding disagreed with Fikry, et al., (2015) who found, no significant difference between the students age, sex and residence.

The data of study results illustrate that, the majority of samples who had good knowledge level were living in urban area. This result from the researcher opinion is due to media and technology in urban more than in rural, presence of clubs which provide a chance for meeting and discussion between students, the health centers, hospital, and services present in urban area more than in rural.

The data of study results illustrate that, the majority of samples who had good knowledge level were females. (Khan et al., 2010) was also in the same line and reported that; female students showed significantly higher awareness in this regard than male students.

The current study showed that, there are statistical significant relation between knowledge level and year of education the highest percentage of the study students with increased knowledge were in the fourth class. This result from the researcher opinion is due to increased the age, experience, and sharing of knowledge with other students. According to Khan et al., (2010) who revealed that, the students above 20 years of age showed higher knowledge for questions than younger age.

Finally, in a study conducted by Min Swe et al., (2012) who added that, a preventive measures, and health education programs can produce positive changes in both knowledge and attitudes toward safety protocols.

\section{Conclusion}

Based on the results of the present study, it can be concluded that:

More than half of the sample had poor knowledge level about hepatitis $\mathrm{C}$ virus. There were statistical 
significant relation between knowledge level and demographic data in the study samples in all items except type of faculties. Whereas the majority of samples who had good knowledge level were females, fourth class, and from urban area.

\section{Recommendations}

Based on the results of the present study the following can be recommended:

For students

- Sufficient relevant written and visual knowledge through suggested instruction brochure \& mass media to facilitate educating the students in theoretical colleges about mode of transmission and prevention of hepatitis $\mathrm{C}$.

- Continuing education programs about the disease, its prevention, and management and infection control between undergraduate students. Because the students are one of the best groups to be addressed for health education regarding hepatitis who could then act as resource of their families.

\section{For further researches}

Replication of the study on a larger probability sample in different geographical areas in Egypt to figure out the main aspects of this problem.

\section{References}

1. Abd El-Nasser, G., \& Abed El baset E., (2013): Assessment of Students Knowledge and Attitude Toward Hepatitis B and $\mathrm{C}$ in Sohag University/Egypt.

2. Anjali S., \& Shikha J., (2011): Prevention of Hepatitis B; knowledge and practices among Medical students.. Health line ISSN 2229-337X 2(2): 8-11.

3. El-Sayed M., (2014): The New National Strategy on Viral Hepatitis. Presentation in a seminar hosted by Al-Ahram Science Clubs, 1 June 2014.

4. El-Zanaty, Fatma \& Ann Way (2009): Egypt Demographic and Health Survey (2008) Cairo, Egypt: Ministry of Health, El-Zanaty and Associates, and Macro International. Available from, mhtml:file:/infection/prevelance hepatitis Egypt.mht.

5. Essa S., Eissa M., Sharaf S., Ibrahim M., \& Hassanin O, (2007): Prevalence of Hepatitis C Virus Infection In El-Ghar Village In Zagazig, Egypt. Journal of Egyptian Public Health Association, Vol. (82), No. (5 \& 6), Pp. 380-404.

6. Fikry F., Ahmed M., El-Sherbini H., \& Saad A., (2015): Preventive Practices Adopted by Hepatitis" C" Patients in Alexandria-Egypt. Life Science Journal, Volume (12), Issue (6), Pp. 29:41.

7. Hassan S., El-Ghitany E., \& El-Sheikh W., (2012): Knowledge, attitude, and lifestyle change among chronic hepatitis $\mathrm{C}$ patient in Alexandria, Egypt: A Fear-Appeal Intervention Journal of American science, 8,( 2): 73 - 79.

8. Housman J., \& Odum M., (2015): Alters and Schiff Essential Concepts for Healthy Living, $7^{\text {th }}$ ed, Jones \& Bartlett Publishers, chapter1 , Pp.8:9

9. Ibrahim \& Madian (2011): Impact of Hepatitis C educational program on Health-Related Quality of Life in Egypt, Journal of American Science; 7 (11): 430- 439.

10. Khan N., Ahmed S., \& Khalid M., (2010): Effect of gender and age on the knowledge, attitude and practice regarding Hepatitis B and C and vaccination status of Hepatitis B among medical students of Karachi, Pakistan. J Pak Med Assoc. 60 (6): 450 - 455

11. Maroof K., Bansal R., Parashar P., \& Sartaj A., (2012): Do the medical, dental and nursing students of first year know about hepatitis B? A study from a university of North India 62 (1) , 2527.

12. Min S, Zin T, \& Bhardwaj A, (2012): The Prevalence of Needle Sticks Injury among Medical Students in Melaka, Malaysia, A Cross Sectional Study, European Journal of Scientific Research, 71 (2): Pp. 214- 220.

13. Naseer K., Sheikh M., \& Muhammad K., (2010): Knowledge, attitude and practice regarding Hepatitis $\mathrm{B}$ and $\mathrm{C}$ and vaccination status of Hepatitis B among medical students of Karachi, Pakistan. PP. 287-89.

14. Razi A., Rehman, R., Naz, S., Ghafoor, F., \& Khan, A., (2010): Knowledge Attitude and Practices of University Students Regarding Hepatitis B and C. Journal of Agricultural and Biological Science, 5 (4 ): 38-43.

15. Tazeem S., Syed M., Zain M., \& Ahmad J., (2014): Hepatitis B and C: Knowledge, attitude and Perception of medical students at Lahore Medical \& Dental College, Lahore. Vol. 8, NO. 3, JUL - SEP PP. 789 - 793.

16. World Health Organization (WHO), (2012): Hepatitis B \& C Fact Sheet No. 204 [Internet]. Dec 12.

17. World Health Organization (WHO), (2012): Prevention \& Control of Viral Hepatitis Infection: Framework for Global Action, Available from http: www who int csr disease hepatitis GHP_framework.

18. Yayehyirad K., Asfaw D., Hailemariam K., Mengistu A., \& Binyam A., (2009): Hepatitis C of Institutions and Persons. Ethio. J. Health Dev. 23 (especial issue) 173-223. 